Paulina Witkowska

Uniwersytet Wrocławski, Wrocław

paulina.witkowska@uwr.edu.pl

\title{
CECHY SŁOWOTWÓRCZE CZASOWNIKÓW OZNACZAJĄCYCH ZMIANĘ POZYCJI CIAŁA WZGLĘDEM OSI CIAŁA
}

\begin{abstract}
Słowa klucze: czasowniki ruchu, szereg słowotwórczy, semantyka prefiksów Keywords: motion verbs, word derivational series, prefix semantics
\end{abstract}

Artykuł omawia cechy słowotwórcze nieopisanej dotąd grupy czasowników z cząstką się oznaczających zmianę pozycji ludzkiego ciała względem osi ciała, czyli osi głównej, biegnącej od szczytu głowy do podstawy ciała. Kluczowe jest to, jak zmienia się położenie tułowia, kiedy stojący człowiek schyla się, prostuje czy odwraca w miejscu, bez przemieszczania się. Do badanego pola leksykalno-semantycznego włączono czasowniki oparte na temacie prefiksalnym oraz bezprefiksalnym. Uwzględniono formacje o dokonanej i niedokonanej wartości kategorii aspektu. Zamieszczone na kolejnych stronach tabele prezentują podział czasowników ze względu na obecność wspólnego rdzenia (Tab. 1) oraz łączliwość prefiksów z różnymi rdzeniami (Tab. 2).

Celem artykułu jest opisanie, w jaki sposób różnice w budowie morfologicznej rozpatrywanych czasowników wpływają na przebieg oznaczanej przez nie zmiany pozycji ciała, tj. ustalenie typów szeregów słowotwórczych prezentujących relacje derywacyjne zachodzące między czasownikami oraz wyjaśnienie, jakie znaczenia do tematów bezprefiksalnych wnoszą poszczególne prefiksy. W opisie wykorzystano metodologię słowotwórstwa synchronicznego, badającego formalną i semantyczną pochodność wyrazów. Analizowano znaczenia nieprzenośne.

1 Przykłady użyć rozpatrywanych czasowników pochodzą ze zbioru zdań pozyskanych za pomocą narzędzi informatycznych (w ramach grantu wewnętrznego 1437/M/IFP/11) z elektronicznych korpusów tekstów: milionowego podkorpusu Narodowego Korpusu Języka Polskiego, Korpusu 
Tab. 1. Podział czasowników ze względu na obecność wspólnego rdzenia.

Rdzeń Czasowniki o aspekcie dokonanym

\begin{tabular}{ll}
-buj- & bujnąć się, rozbujać się \\
\hline -chw'- & zachwiać się \\
\hline -chyb- & chybnąć się, zachybotać się \\
-chyl'-/- & $\begin{array}{l}\text { nachylić się, naschylać się, odchylić się, } \\
\text { pochylić się, przechylić się, przychylić się, } \\
\text { schylić się, uchylić się, wychylić się }\end{array}$ \\
-chyl- & wzdrygnąć się \\
\hline -g'- & $\begin{array}{l}\text { nagiąć się, odgiąć się, przegiąć się, przygiąć } \\
\text { się, ugiąć się, wygiąć się, zgiąć się }\end{array}$
\end{tabular}

-garb'- pogarbić się, przygarbić się, zgarbić się

$\begin{array}{lll}\text {-gib- } & \text { gibnąć się } & \text { gibać się } \\ \text {-kiw- } & \text { kiwnąć się, pokiwać się } & \text { kiwać się }\end{array}$

-kłań-/-

-kłoń-

odkłonić się, pokłonić się, skłonić się

$\begin{array}{ll}\text {-kołys- } & \text { pokołysać się, rozkołysać się, zakołysać się } \\ \text {-kręć-/- } & \text { nakręcić się, odkręcić się, okręcić się, pokrę- } \\ \text {-kręc- } & \begin{array}{l}\text { cić się, poodkręcać się, wykręcić się, zakręcić } \\ \text { się }\end{array}\end{array}$

\section{-kul'-/-}

-kul-

$-\mathbf{p}^{\prime}-$ przykulić się, skulić się

-pręż-

wypiąć się

-prost- rozprostować się, wyprostować się

$\begin{array}{lll}\text {-telep- } & \text { zatelepać się } & \text { telepać się } \\ \text {-trząś-/- } & \text { natrząść się, zatrząść się, wstrząsnąć się } & \text { trząść się, wstrząsać się } \\ \text {-trząs- } & \text { wahnąć się } & \text { wahać się } \\ \text {-wah- } & \text { wah }\end{array}$

-(w)róć-/-

$-(\mathbf{w})$ rac $^{2}$ obrócić się, odwrócić się kłaniać się, odkłaniać się, skłaniać się

Czasowniki o aspekcie niedokonanym bujać się

chwiać się

chybotać się

chylić się, nachylać się, odchylać się, pochylać się, przechylać się, przychylać się, schylać się, uchylać się, wychylać się, wzdrygać się

giąć się, naginać się, odginać się, powyginać się, przeginać się, przyginać się, uginać się, wyginać się, zginać się garbić się

kołysać się

kręcić się, odkręcać się, okręcać się, wykręcać się

kulić się, przykulać się, skulać się

wypinać się

prężyć się, wyprężać się

prostować się, rozprostowywać się, wyprostowywać się

obracać się, odwracać się, poobracać się

Języka Polskiego IPI PAN, Korpusu Słownika Frekwencyjnego, Korpusu „Rzeczpospolitej” oraz korpusu internetowego (danych językowych pochodzących z Internetu, zebranych na Politechnice Wrocławskiej).

2 W wypadku formacji odwrócićlodwracać, obrócić/obracać, a także poobracać, przyjęto etymologiczny punkt widzenia. Są one oparte na wspólnym rdzeniu -(w)róć-/-(w)rac-. Jak podaje A. Brückner (SEBr: 372, 632-633), u ich źródła leży słowo wrot, będące podstawą słowotwórczą wrócić/wracać, które występują w połączeniu z różnymi prefiksami. W formach z prefiksem 
Tab. 2. Łączliwość prefiksów z różnymi rdzeniami³.

\begin{tabular}{|c|c|c|c|c|c|c|c|c|c|c|c|c|c|c|c|c|}
\hline Rdzeń & 光 & $\frac{\frac{1}{0}}{\frac{0}{0}}$ & $\underbrace{\frac{1}{0}}_{\underset{\theta}{0}}$ & $\stackrel{1}{\varrho}$ & d & 究 & 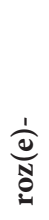 & $\stackrel{1}{=}$ & $\frac{\frac{1}{0}}{\frac{1}{3}}$ & 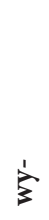 & $\frac{\frac{\dot{j}}{j}}{\frac{\dot{b}}{\frac{1}{N}}}$ & $\stackrel{⿱ ⺌}{\mathfrak{N}}$ & 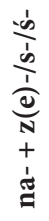 & $\begin{array}{l}\frac{1}{0} \\
\frac{0}{0} \\
\frac{1}{0} \\
+ \\
\vdots \\
0\end{array}$ & 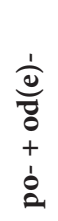 & $\begin{array}{l}1 \\
3 \\
+ \\
\vdots \\
\vdots\end{array}$ \\
\hline -buj- & & & & + & & & + & & & & & & & & & \\
\hline -chw'- & & & & & & & & & & & & + & & & & \\
\hline -chyb- & & & & & & & & & & & & + & & & & \\
\hline $\begin{array}{l}\text {-chyl'-/- } \\
\text {-chyl- }\end{array}$ & + & & + & + & + & + & & + & & + & + & & + & & & \\
\hline -dryg- & & & & & & & & & + & & & & & & & \\
\hline -g'- & + & & + & & + & + & & + & & + & + & & & & & + \\
\hline -garb'- & & & & + & & + & & & & & + & & & & & \\
\hline
\end{tabular}

-gib-

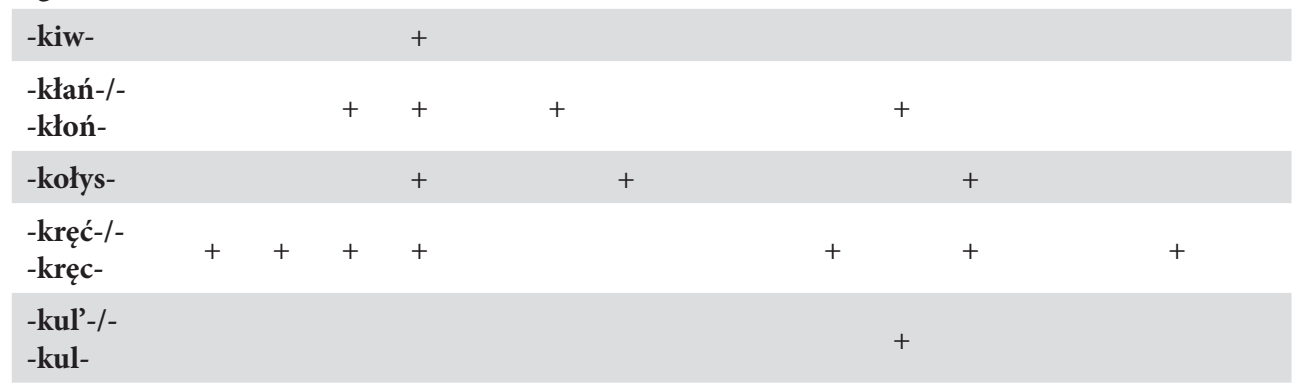

$\begin{array}{lc}-\mathbf{p}^{\prime}- & + \\ - \text { pręż- } & +\end{array}$

-prost- $++\quad+$

-telep-
$\begin{aligned} & \text {-trząś-/- } \\ & \text {-trząs- }\end{aligned}$
-wah-

$-(\mathbf{w})$ róć-/-

$-(\mathrm{w})$ rac-

$o$-/ob(e)-fonem /v/ z nagłosu rdzenia uległ po fonemie /b/ zanikowi z przyczyn fonotaktycznych ( ${ }^{*}$ obwrócić, ${ }^{*}$ obwracać, ${ }^{\star}$ obwrót $)$.

3 Czasowniki ruchu we współczesnej polszczyźnie występują z 16 prefiksami rodzimymi: do-, na-, nad(e)-, o-/ob(e)-, od(e)-, po-, pod(e)-, prze-, przy-, roz(e)-, u-, w(e)-, w(e)z-/w(e)s-, wy-, z(e)-/s-/s'-, $z a$ - (por. Striekałowa 1962; Śmiech 1986; Wróbel 1999: 539). Wśród włączonych do badanego pola znaczeniowego czasowników prefiksalnych można wyróżnić formacje z prefiksami złożonymi. 


\section{Szeregi słowotwórcze}

Z punktu widzenia słowotwórstwa synchronicznego rozpatrywane czasowniki z cząstką się należy uznać za derywaty pseudozwrotne (Wróbel 1999: 554-555), powstałe w wyniku derywacji postfiksalnej: postfiks się podkreśla odniesienie rezultatu zmiany pozycji ciała (zamierzonej lub niezamierzonej) do subiektu ${ }^{4}$. Poniżej przedstawiono różne typy łańcuchów derywacyjnych tworzące odpowiadające badanym czasownikom formy bez się. Formacje oparte na temacie prefiksalnym i bezprefiksalnym ułożono w kolejności ich utworzenia, biorąc za podstawę zachodzące między nimi związki formalne i semantyczne. Przy każdej formie (w nawiasach okrągłych) umieszczono cząstkę się jako wykładnik derywacji postfiksalnej. Struktura danego łańcucha zależy od liczby i rodzaju derywatów.

Typ pierwszy to szereg o strukturze: bezprefiksalny czasownik niedokonany $(+$ się $) \rightarrow$ prefiksalny czasownik dokonany $(+$ się $) \rightarrow$ wtórny czasownik niedokonany (+ się). To typ szeregu, który obejmuje zdecydowaną większość badanych czasowników, np.

$\begin{array}{ll} & \text { nachylić (się) } \rightarrow \text { nachylać (się) } \\ & \text { odchylić (się) } \rightarrow \text { odchylać (się) } \\ & \text { pochylić (sié) } \rightarrow \text { pochylać (się) } \\ \text { chylić (się) } \rightarrow & \text { przechylić (się) } \rightarrow \text { przechylać (się) } \\ & \text { przychylić (się) } \rightarrow \text { przychylać (się) } \\ & \text { schylić (się) } \rightarrow \text { schylać (się) } \\ & \text { uchylić (sié) } \rightarrow \text { uchylać (sié) } \\ & \text { wychylić (się) } \rightarrow \text { wychylać (się) } \\ \text { prostować (się) } \rightarrow \quad & \text { rozprostowá́ (się) } \rightarrow \text { rozprostowywać (się) } \\ & \text { wyprostować (się) } \rightarrow \text { wyprostowywać (się) }\end{array}$

Bezprefiksalny czasownik niedokonany oraz powstały w wyniku derywacji prefiksalnej czasownik dokonany tworzą wtórną parę aspektową, z kolei prefiksalny czasownik dokonany oraz powstały w wyniku derywacji paradygmatycznej wtórny czasownik niedokonany tworzą czystą parę aspektową̧5. Czasowniki z postfiksem się

4 Z punktu widzenia semantyki funkcja cząstki się nie jest tak jednoznaczna. W wystąpieniach niektórych czasowników można dopatrywać się jej użycia w funkcji leksykalnej. Chodzi o wypadki, kiedy zmiana pozycji ciała zachodzi z woli subiektu i pod jego kontrolą. Subiekt, wykonując ruch siłą własnych mięśni, działa w istocie sam na siebie. Wykonawca czynności jest więc tożsamy z jej przedmiotem (swoim ciałem). Za dopuszczalną można też uznać wymianę się na siebie, np. Wyprostowat się dumnie $\rightarrow$ Wyprostowat siebie (swoje ciało) dumnie.

5 W synchronicznym opisie słowotwórstwa czasowników wyróżnia się pary aspektowe czyste oraz wtórne (Laskowski 1999: 157-171). W wypadku czystej pary aspektowej różnica między leksemami sprowadza się tylko do odmiennej wartości kategorii aspektu. Między leksemami tworzącymi wtórną parę aspektową oprócz różnicy aspektu zachodzi różnica w znaczeniu. Przy ustalaniu, jaki typ pary aspektowej reprezentują dwa czasowniki, istotną rolę odgrywa test wtórnej imperfektywizacji. Czasowniki V1 i V2 (np. chylić i nachylić) nie stanowią czystej pary aspektowej, jeżeli 
tworzą pary aspektowe analogiczne do par aspektowych tworzonych przez równobrzmiące czasowniki bez się (np. chylić się i nachylić się to wtórna para aspektowa, podobnie jak chylić i nachylić; nachylić się i nachylać się to czysta para aspektowa, podobnie jak nachylić i nachylać).

Typ drugi to szereg o strukturze: bezprefiksalny czasownik niedokonany $(+$ się $) \rightarrow$ $\rightarrow$ prefiksalny czasownik dokonany $(+s i e ̨) \rightarrow$ wtórny czasownik niedokonany $(+s i e) \rightarrow$ $\rightarrow$ dystrybutywny czasownik dokonany $(+$ się), np.

$$
\begin{array}{llll}
\text { giąć }(\text { się }) \rightarrow & \text { wygiąć }(\text { się }) \rightarrow & \text { wyginać }(\text { się }) \rightarrow & \text { powyginać }(\text { się }) \\
\text { kręcić }(\text { się }) \rightarrow & \text { odkręcić }(\text { się) } \rightarrow & \text { odkręcać }(\text { się }) \rightarrow & \text { poodkręcać }(\text { się })
\end{array}
$$

Wtórny prefiksalny czasownik niedokonany oraz będący jego derywatem prefiksalny czasownik dokonany stanowią wtórną parę aspektową, ponieważ oprócz różnicy aspektu zachodzi między nimi różnica w znaczeniu: utworzony za pomocą prefiksu po- czasownik dokonany ma znaczenie dystrybutywne ${ }^{6}$. Parę taką tworzą również czasowniki z się, analogicznie do odpowiadających im czasowników bez się (np. wyginać się i powyginać się to w tórna para aspektowa, podobnie jak wyginać i powyginać).

Typ trzeci to szereg o strukturze: bezprefiksalny czasownik niedokonany $(+$ sie $) \rightarrow$ $\rightarrow$ prefiksalny czasownik dokonany $(+$ się), np.

$$
\begin{aligned}
& \begin{array}{ll}
\text { kołysać }(\text { się }) \rightarrow & \begin{array}{l}
\text { pokołysać (się) } \\
\text { rozkołysać (się) }
\end{array}
\end{array} \\
& \text { zakołysać (się) } \\
& \text { nakręcić (się) } \\
& \text { kręcić }(\text { się }) \rightarrow \quad \text { pokręcić (się) } \\
& \text { zakręcić (się) } \\
& \begin{array}{ll}
\text { garbić }(\text { się }) \rightarrow & \text { pogarbić (się) } \\
\text { zgarbić (się) }
\end{array}
\end{aligned}
$$

Mimo że od członów dokonanych powyższych par nie można utworzyć czasowników niedokonanych, to czasowniki bezprefiksalne oraz będące ich derywatami czasowniki prefiksalne nie stanowią w większości wypadków czystych par aspektowych. Oprócz różnicy aspektu zachodzi między nimi różnica znaczenia. Czystych par aspektowych nie tworzą także czasowniki z się, analogicznie do odpowiadających im czasowników bez się (np. kolysać się i zakolysać się to wtórna para aspektowa,

od członu dokonanego V2 można utworzyć czasownik niedokonany $\mathrm{V}_{3}$ (nachylać). Wówczas para czasowników V1 i V2 stanowi wtórną parę aspektową, natomiast para czasowników V2 i V3 czystą parę aspektową. Pozytywny wynik testu nie jest jednak wystarczający; między członami czystej pary aspektowej nie mogą wystąpić różnice inne niż aspekt.

6 Formacje dystrybutywne oznaczają akcje dynamiczne, ukierunkowane na wiele obiektów lub mające wiele subiektów (Grzegorczykowa 1984: 82-83; Wróbel 1999: 549). 
podobnie jak kołysać i zakołysać). Wydaje się, że o różnicy tylko aspektowej można mówić w wypadku par czasowników: garbić się i zgarbić się, garbić się i pogarbić się.

Typ czwarty to szereg o strukturze: bezprefiksalny czasownik niedokonany $(+$ się $) \rightarrow$ bezprefiksalny czasownik dokonany $(+$ się), np.

$\begin{array}{ll}\text { bujać }(\text { się }) \rightarrow & \text { bujnąć }(\text { się) } \\ \text { chybotać }(\text { się) } \rightarrow & \text { chybnąć }(\text { się) } \\ \text { gibać }(\text { się) } \rightarrow & \text { gibnąć }(\text { się) } \\ \text { kiwać }(\text { się }) \rightarrow & \text { kiwnąć }(\text { się) }\end{array}$

Formant paradygmatyczny wnosi do derywatów znaczenie krótkotrwałości i jednokrotności względem podstaw neutralnych co do czasu trwania7. Różnica pomiędzy podstawowymi czasownikami niedokonanymi a utworzonymi od nich czasownikami dokonanymi nie sprowadza się tylko do odmiennej wartości kategorii aspektu. Czystych par aspektowych nie tworzą zarówno pary czasowników bez się (np. bujać i bujnać), jak i pary czasowników z się (np. bujać się i bujnąć się).

Typ piąty to szereg obejmujący niektóre z czasowników nieposiadających odpowiedników bez się o strukturze: bezprefiksalny czasownik niedokonany z się $\rightarrow$ prefiksalny czasownik niedokonany z się $\rightarrow$ prefiksalny czasownik dokonany z się, np.

kłaniać się $\rightarrow$ odkłaniać się $\rightarrow$ odkłonić się

Powstały w wyniku derywacji prefiksalnej czasownik niedokonany z się oraz powstały w wyniku derywacji paradygmatycznej czasownik dokonany z się tworzą czystą parę aspektową.

\section{Semantyka prefiksów ${ }^{8}$}

Ustalenie kolejności członów szeregów słowotwórczych oraz wyjaśnienie zachodzących między nimi relacji derywacyjnych umożliwiło analizę wpływu prefiksów na znaczenia rozpatrywanych czasowników ruchu.

7 Za derywaty uznano czasowniki z sufiksem tematycznym -ną- (-n-), ponieważ są one bardziej złożone pod względem semantycznym. O ile czasowniki bujać (się), chybotać (się), gibać (się), kiwać (się) nazywają miarowy ruch wahadłowy, który składa się z powtarzalnych ruchów jednokrotnych, przebiegających kilkakrotnie w przeciwnych kierunkach, o tyle czasowniki bujnąć (się), chybnąć (się), gibnąć (się), kiwnąć (się) nazywają ruch jednokrotny lub krótkotrwały. Formacje oznaczające krótkotrwałość i jednokrotność akcji określane są jako semelfaktywne (Wróbel 1999: 548-549).

8 Opracowano na podstawie: Striekałowa 1962; Bojar 1979; Grzegorczykowa 1984; Śmiech 1986; Janowska 1999; Laskowski 1999; Wróbel 1999; USJP; Wiland 2012. 
2.1. Prefiks na- w nachylić się, nagiąć się wyraża zbliżenie się do jakiegoś punktu w przestrzeni na niewielki dystans poprzez zmianę pozycji ciała na niższą. Użyciom tych czasowników towarzyszy często kontekst do + D., ku + C., nad + N., który wskazuje konkretny cel ruchu, np. - Nachyl się do mnie i uściśnij mnie na dobranoc! Wsparty prawą ręką o stół, nachylił się ku rozmówczyni. Nagiął się nad woda $i$ wydobył dryfujące pióro. Wydaje się, że prefiks na- oprócz znaczenia kierunkowego wprowadza też znaczenie saturatywne: sygnalizuje zmianę pozycji w stopniu wystarczającym, aby osiągnąć bliskość. W wypadku nakręcić się, naschylać się i natrząść się można mówić o znaczeniu saturatywnym i akumulatywnym ${ }^{10}$ : prefiks $\boldsymbol{n a}$ - sygnalizuje wysoką intensywność, wraz z towarzyszącym odczuciem przesytu lub zmęczenia (por. Śmiech 1986: 23, 47-48), oraz wielokrotność akcji wskazywanej przez czasownik bezprefiksalny kręcić się, schylać się, trzaść się, np. Zawodnicy nakręcili się $w$ tańcu, że aż nogi bolaty, a pot zalewał oczy. Trzy dni potrzeba byto pracować na dwa złote, i to pracować naprawdę, nażąć kope rzadkiego żyta, naschylać się, napocić, i snopów nadźwigać. Ile czasu trzeba było się natrząść na wozie, żeby dotrzeć z Culloden do Broch Tuarach? Użycie czasownika natrzaśś się wskazuje na intensywność i wielokrotność niezależnych od woli subiektu drgań, którym uległ on podczas długotrwałej jazdy niewygodnym środkiem lokomocji.

2.2. Prefiks o-/ob(e)- w okręcić się, obrócić się sygnalizuje ruch wokół własnej osi, np. Bramkarz okręcit się kilka razy wkoło, jakby mu się do pleców przyczepił kleszcz. Zanim dwukrotnie obrócisz się wokót swojej osi, będziemy gotowi, lub wokól jakiegoś przedmiotu, np. Minęła widocznie dwudziesta trzecia, bo ekran przecięła nagle stalowa rura, wokót której okręciła się naga kobieta. W obrócić się prefiks o-/ob(e)- może też wyrażać zwrócenie się w stronę jakiegoś punktu w przestrzeni poprzez ruch wokół własnej osi, na co wskazuje kontekst $d o+$ D., $k u+C$., np. Instynktownie obrócit się plecami do rywala. Schował miecz chwile wcześniej, zanim oficer obrócił się ku niemu. O ile użycia czasownika okręcić się wskazują, że subiekt wykonał pełny obrót dookoła własnej osi lub jakiegoś obiektu, o tyle z użyć czasownika obrócić się wynika, że tor ruchu subiektu mógł mieć kształt okręgu (pełny obrót) lub łuku (niepełny obrót), por. Dziewczynka popatrzyła w lustro i obróciła się kilkakrotnie.

2.3. Prefiks od(e)- w odchylić się, odgiąć się wnosi znaczenie kierunkowe: wyraża oddalenie się od jakiegoś punktu w przestrzeni na niewielki dystans poprzez zmianę pozycji ciała na ukośną w stosunku do pionu, np. Odchylit się i zamiast w szyję zostat ugodzony niegroźnie w klatkę piersiową. Odgiąt się w pasie i spojrzat na wznoszące się nad nim urwisko. Połączeniom prefiksu od(e)-z rdzeniem -chyl'-/-chyl-towarzyszy często określony typ kontekstu, który wskazuje konkretny kierunek ruchu, a także przyczynę oddalenia się, np. Schylit się i odskoczył w tyt, szarpnięciem uwalniając

\footnotetext{
9 Formacje saturatywne wskazują na wysoki stopień intensywności i efektywności akcji, innymi słowy, wysoki stopień nasycenia subiektu akcją (Wróbel 1999: 550).

10 Formacje akumulatywne wskazują na sumowanie porcji akcji (ibid.: 549).
} 
zakleszczony miecz, a potem odchylit się $w$ bok przed ponownym cięciem topora. Chcac zwiększyć odległość między soba i rozmówca, nieznacznie odchylit się do tyłu.

$\mathrm{W}$ odkręcić się, odwrócić się prefiks od(e)- wyraża zwrócenie się, poprzez ruch obrotowy, w stronę inną od przyjmowanej w celu albo oddalenia się (zwrot tyłem ciała; od $+D$.), albo zbliżenia się do jakiegoś punktu w przestrzeni (zwrot przodem ciała; do + D.), np. Wyniośle odkręciła się do niego plecami. Odwrócił się do niej, wtedy spostrzegła na twarzy jego wyraz smutku i przygnębienia. Odwrócił się od nich, nie chcąc być świadkiem czułej sceny.

Z kolei w odkłaniać się prefiks od(e)- nie wnosi znaczenia kierunkowego; wyraża powtarzanie czynności oznaczanej przez czasownik bezprefiksalny kłaniać się w odpowiedzi, np. A ja im się odkłaniałem albo, zdejmując z rozmachem kapelusz, przesadnie składałem swoje uszanowanie. Znaczenie tego czasownika można sparafrazować jako 'odpowiadać, kłaniając się'.

2.4. W pochylić się oraz pokłonić się prefiks po-, który można zastąpić prefiksem $z(e)-/ s-/ s^{\prime}$, wyraża ruch z góry ku dołowi i w przód, np. Pochylili się, aby nazbierać smakowitych podgrzybków. Kanclerz pokłonił się nisko, pochylając wdzięcznie plecy. Czasownik pokłonić się jest względem pochylić się bogatszy pod względem semantycznym: zmiana pozycji ciała na niższą służy powitaniu lub pożegnaniu kogoś, okazaniu szacunku. W wypadku pogarbić się, np. Pogarbił się, a jego ciało zaczęło przypominać wilka stojącego na tylnych łapach, zmianie pozycji ciała na niższą towarzyszy ściągnięcie ramion i zaokrąglenie pleców; można tu zatem mówić także o ruchu w kierunku od zewnątrz do wewnątrz (wnętrza ciała). Zakres ruchu w pogarbić się jest mniejszy niż w pochylić się czy pokłonić się; w tym sensie prefiks po- wnosi też znaczenie deminutywne ${ }^{11}$.

Prefiks po- w pokiwać się, pokotysać się, pokręcić się nadaje czynności nazywanej przez czasownik bezprefiksalny kiwać się, kołysać się, kręcić się znaczenie determinatywne ${ }^{12}$ : sygnalizuje, że czynność trwała przez pewien czas. Czasownik pokręcić się oznacza, że przez pewien czas obracano się wokół własnej osi, w jedną lub w drugą stronę, np. Pokręcit się w kółko przez całe dziesięć sekund, zanim odwrócit się z powrotem twarza do mnie. Z kolei czasowniki pokołysać się, pokiwać się oznaczają, że przez pewien czas przechylano się w przeciwne strony, raz w jedną, raz w drugą, np. Mężczyzna pokiwat się z obcasów na palce przed przylepionymi na ścianie plakatami filmowymi. Teraz możemy pokotysać się w przód i $w$ tył, w rytm wdechów $i$ wydechów. Ponieważ kilkakrotne, powtarzające się ruchy są ujmowane jako pewna całość, można stwierdzić, że prefiks po- w omawianych formacjach wprowadza też znaczenie akumulatywne.

11 Formacje deminutywne wskazują na niski stopień intensywności i efektywności akcji (por. Wróbel 1999: 551).

12 Formacje determinatywne oznaczają sytuacje ograniczone czasowo lub przestrzennie (Grzegorczykowa 1984: 81; Wróbel 1999: 546-547). 
W poobracać się, poodkręcać się, powyginać się prefiks po- wnosi znaczenie typowo dystrybutywne: użycia tych czasowników odnoszą się do wielu subiektów, np. Towarzysze wycieczki poobracali się do mnie tyłem i nikt mnie nie podglądał. Powyginali się i połączyli w ten sposób, że na chwilę zmienili się w dwugarbnego wielbłada. Górnicy poodkręcali się do nas tyłem na znak protestu przeciwko rychłej likwidacji kopalni. W wypadkach, kiedy subiekt jest pojedynczy, można mówić o akumulatywności: wielokrotne, powtarzające się ruchy ujmowane są jako pewna całość, np. Poobracaj się, sprawdź, czy suknia dobrze się układa. We wtorek byłem po raz pierwszy na siłowni, $w$ czwartek $i w$ piatek trochę się powyginatem.

2.5. Prefiks prze- w przechylić się, przegiać się wyraża zmianę pozycji ciała na ukośną w stosunku do pionu, np. W pewnym momencie chłopiec przechylił się przez barierkę $i$ wpadł do wody. Klucznik przegiąt się przez obmurowanie studni i wyciagnąt rękę po klejnot. Kontekst przez + B. sygnalizuje przemieszczenie tułowia z jednej strony obiektu na drugą przy jednoczesnym przekroczeniu tego obiektu (punktu w przestrzeni); można tu zatem mówić o znaczeniu perlatywnym i ekscesywnym ${ }^{13}$ wnoszonym przez prefiks prze-.

2.6. Prefiks przy-w przychylić się, podobnie jak prefiks na- $w$ nachylić się, wyraża zbliżenie się do jakiegoś punktu w przestrzeni na niewielki dystans poprzez zmianę pozycji ciała na ukośną w stosunku do pionu, np. Kobieta przychyliła się trochę, żeby szepną́ mu coś do ucha. Oprócz znaczenia kierunkowego prefiks wnosi też znaczenie saturatywne: sygnalizuje wykonanie czynności w wystarczającym stopniu, aby osiągnąć bliskość. Z kolei w przygarbić się, przygiąć się, przykulić się oraz w niektórych użyciach przychylić się prefiks przy- wprowadza znaczenie deminutywne: wskazuje na niewielki zakres ruchu oraz częściową, niepełną realizację czynności lub stanu, np. Przygarbit się nieco, bo sufit był bardzo niski. Ciężko mu było wejść, ale jak dobrze się przygiąt, tak i wszedł. Przykulit się i przyspieszył kroku. Poszła do waskiego przejścia między sadem a szopa, nakrytego obwistymi pod śniegiem gałęziami, $\dot{z}$ e musiała się przychylić. Formacje te przeciwstawiają się formacjom z przedrostkiem $\boldsymbol{z}(\boldsymbol{e})-/ \mathbf{s}-/ \boldsymbol{s}^{\mathbf{p}}$, sygnalizującym całościową, pełną realizację czynności lub stanu, por. przygarbić się 'nie całkiem się zgarbić', przygiąć się 'nie całkiem się zgiąc', przykulić się 'nie całkiem się skulić', przychylić się 'nie całkiem się schylić'.

2.7. Prefiks roz(e)- w rozprostować się oznacza ruch z dołu ku górze: subiekt przyjął pozycję pionową, w wyniku czego stał się wizualnie wyższy, np. Wstał i rozprostowat się na cała swoja wysokość. Znaczenie tego czasownika można sparafrazować jako 'rozciągnąć się, prostując'. W rozbujać się i rozkołysać się prefiks roz(e)- wprowadza znaczenie ewolutywne ${ }^{14}$ : wyraża osiągnięcie odpowiedniej intensywności

13 Perlatywność oznacza przemieszczenie obiektu z jednego miejsca na drugie (por. Wróbel 1999: 557). Ekscesywność to z kolei termin określający przekroczenie jakiegoś punktu granicznego (zob. Wiland 2012).

14 Formacje ewolutywne wskazują na stopniowy rozwój akcji, aż do osiągnięcia jej odpowiedniej intensywności (Wróbel 1999: 551). 
ruchu wahadłowego, odbywającego się miarowo w przeciwległych kierunkach, np. Zaczęła coraz mocniej się kołysać, do przodu, do tyłu, aż się rozbujała. Hrabina zaczęła ponownie kiwać głowa, całe jej ciało rozkotysało się, a z gardła wydobył się niski, dźwięczny głos. Znaczenie tych czasowników można sparafrazować jako: 'rozpędzić się, bujając', 'rozpędzić się, kołysząc'.

2.8. Prefiks $\boldsymbol{u}$ - w uchylić się wyraża oddalenie się od jakiegoś punktu lub obiektu w przestrzeni poprzez zmianę pozycji ciała na ukośną w stosunku do pionu. Towarzyszący użyciom tego czasownika kontekst wskazuje, że celem oddalenia się jest uniknięcie jakiegoś zagrożenia (ciosu, uderzenia itp.), np. Uchylit się przed następnym ciosem, szukając jakiejś broni. Uchylita się przed wymierzonym w nia uderzeniem. Szybkim ruchem zdołał uchylić się na bok i uniknąt cięcia. W czasowniku ugiać się, używanym zwykle na oznaczenie ruchu niezależnego od woli subiektu, prefiks $\boldsymbol{u}$ - sygnalizuje obniżenie tułowia wskutek nacisku, np. Aż ugiąt się pod ciężarem worka dźwiganego na plecach.

2.9. Czasowniki $z$ prefiksem $w(e) z-/ w(e) s-$ oznaczają najczęściej ruch $w$ górę, np. wznieść się, wspiąć się, wzrosnąć, wskoczyć. W wypadku wzdrygnać się oraz wstrząsnąc się prefiks ten wnosi przede wszystkim informację o gwałtowności i krótkotrwałości akcji (znaczenie semelfaktywne), która zachodzi wskutek doznania jakiegoś niemiłego uczucia, związanego ze stanem emocjonalnym lub percepcją zmysłową, np. Wzdrygnąt się od chłodu, a może pod wplywem nowego nawrotu niepokoju. Wstrząsnęta się nerwowo i po jej pięknej twarzy przeleciał blysk wstrętu i obrzydzenia. Gwałtownemu wstrząsowi lub drgnięciu może towarzyszyć widoczne uniesienie ciała.

2.10. Czasowniki wychylić się, wygiać się oznaczają zmianę pozycji ciała na ukośną w stosunku do pionu, np. Wychyliła się do przodu i próbowała odczytać reakcje $z$ oczu rozmówcy. Uderzony niespodziewanie $w$ plecy mężczyzna wygiąt się $w$ tuk. Użyciom tych czasowników towarzyszy często kontekst przez + B., poza + B., $z a+$ B., który sygnalizuje, że ruch wykonywany jest nie tylko poza pionową oś ciała, ale także poza obręb jakiegoś obiektu, np. Wychylit się przez okno, gdy próbował nasypać jedzenia do karmnika i wtedy wypadt. Ostrożnie wychylit się poza krawędź występu, by spojrzeć $w$ dół. Podeszła do relingu, wychyliła się za burtę i zniknęła. Ów burżuj wstał spod futer $i$ wygią się przez sań oparcie, sieggając lampy zadniej. Prefiks wy-, podobnie jak prefiks prze-, wprowadza znaczenie perlatywne i ekscesywne. Użycia czasownika wychylić się z kontekstem $z z a+\mathrm{D}$. lub $z+\mathrm{D}$., np. Nagle ktoś wychylit się zza rogu budynku i strzelit. $Z$ okna wychyliła się kobieta, oznaczają wyłonienie się subiektu poza obręb jakiego obiektu.

Prefiks $w y$ - w wykręcić się sygnalizuje, że subiekt zwrócił przód swojego ciała w stronę inną od przyjmowanej, wykonując ruch obrotowy, np. Wykręcil się w prawo i zobaczył niemieckiego komandosa pochylonego nad ofiarą. Spróbowat się wykręcić do tyłu, choć ból wyciskał mu łzy z oczu. 
Z kolei w wyprężyć się, wyprostować się prefiks $w y$-, podobnie jak prefiks roz(e)-, wyraża ruch w górę: subiekt przyjął pozycję pionową, w wyniku czego stał się wizualnie wyższy, np. Tysiąc żołnierzy wyprężyło się jak struny, prezentując broń. Wreszcie wyprostowat się, unióst twarz ku górze. Jeśli chodzi o czasownik wypiąć się, to w zależności od kontekstu oznacza on albo ruch z dołu ku górze (przy wypięciu klatki piersiowej), np. Stuknawszy kijami w podłogę, nieudolnie wypięli się na baczność, albo ruch z góry ku dołowi (przy wypięciu pośladków), np. Wypiął się aż tak mocno, że z trzaskiem puścily jego spodnie w szwach.

2.11. Prefiks $\boldsymbol{z}(\boldsymbol{e})-/ \boldsymbol{s}-/ \boldsymbol{s}-\mathrm{w}$ schylić się, zgiąć się oraz skłaniać się sygnalizuje ruch z góry ku dołowi i w przód, np. Upuścit paczkę, schylit się, żeby ją podnieść, i upuścit dwie dalsze. Nagle uderzył w nich silny podmuch wiatru, aż zgięli się $w$ pót, aby nie upaść. Uśmiechając się, witał tych, co mu się skłaniali nisko. W wypadku czasownika skłaniać się zmiana pozycji ciała na niższą służy powitaniu lub pożegnaniu kogoś, okazaniu szacunku. W skulić się oraz zgarbić się zmianie pozycji ciała na niższą towarzyszy ściągnięcie ramion i zaokrąglenie pleców; można tu zatem mówić o ruchu w kierunku od zewnątrz do wewnątrz (wnętrza ciała), np. Dziewczyna skuliła się przepraszająco. W dzieciństwie przypisywałem tę królewską postawe żelaznemu gorsetowi, w którym trudno było jej się zgarbić, a cóż dopiero schylić. Zakres ruchu w skulić się oraz zgarbić się jest mniejszy niż w schylić się, w tym sensie prefiks $z(e)-/ s-/ s-$ wnosi też znaczenie deminutywne.

W zachwiać się, zachybotać się, zakołysać się, zakręcić się, zatelepać się, zatrzaşć się prefiks $z \boldsymbol{a}$ - wnosi znaczenie semelfaktywne: wyraża krótkotrwałość lub jednokrotność akcji, np. Mężczyzna najprawdopodobniej zachwiat się na rusztowaniu i runął $z$ wysokości pięciu metrów. Schodząc w dół, zachybotała się na obluzowanym kamieniu. Rozpostarła ręce jak skrzydła do lotu i zakolysała się na koniuszkach palców. Zakręciła się w miejscu, jakby strzałą ugodzona. Zatelepał się, sycząc z bólu. Zatrzast się z zimna i zębami zazgrzytat.

\section{Podsumowanie}

Obserwacja połączeń poszczególnych prefiksów z różnymi tematami bezprefiksalnymi umożliwiła opis ich wielofunkcyjności słowotwórczej i wieloznaczności. Podstawowe znaczenie, które prefiksy wnoszą do rozpatrywanych czasowników z cząstką się, to znaczenie kierunkowe. Przedrostki charakteryzują też akcje oznaczane przez formacje bezprefiksalne pod względem czasowym, ilościowym oraz pod względem stopnia intensywności i efektywności.

W wyniku prefiksacji bezprefiksalne tematy czasownikowe uzyskują wiele różnych odcieni znaczeniowych. Dla przykładu czasownik chylić się oznacza tyle, że subiekt zmienia pozycję na niższą i ukośną w stosunku do pionu. Prefiksy wprowadzają nową informację. Prefiksy na- w nachylić się (nad stołem) oraz przy- w przychylić się 
(do rozmówcy) sygnalizują, że subiekt, wykonując ruch tułowiem, wyraźnie zbliżył się do jakiegoś punktu w przestrzeni na niewielki dystans. Prefiks przy- w przychylić się (nieco) wskazuje ruch o niewielkim zakresie, jak w przygiąć się czy przygarbić się. Z kolei prefiks od(e)- w odchylić się (do tyłu) informuje o oddaleniu się subiektu. Prefiks $\boldsymbol{u}$ - w uchylić się (przed ciosem) również sygnalizuje oddalenie się subiektu, ale zwykle, jak podpowiada kontekst, w celu uniknięcia jakiegoś zagrożenia. Prefiks prze- w przechylić się (przez barierkę), podobnie jak prefiks wy- w wychylić się (za burte), wyraża odchylenie się subiektu w pionie, przemieszczenie tułowia oraz przekroczenie pewnego punktu w przestrzeni ${ }^{15}$.

Pod wpływem prefiksu zmienia się charakter czynności, na którą wskazuje czasownik podstawowy. Dla przykładu prefiks po- w pokiwaćsię, pokołysać się, pokręcić się wprowadza znaczenie determinatywne (ograniczenie czasowe), a w poobracać się, poodkręcać się, powyginać się - znaczenie dystrybutywne (wielu subiektów). Prefiks przy-w przygarbić się, przygiać się, przykulić się wnosi znaczenie deminutywne (niewielki zakres ruchu), natomiast w przychylić się - znaczenie kierunkowe (zbliżenie się subiektu), a także saturatywne (nasycenie subiektu akcją) lub deminutywne. Prefiks roz(e)- w rozprostować się sygnalizuje ruch w kierunku z dołu ku górze, a w rozbujać się, rozkołysać się wskazuje na ewolutywność akcji (rozwój akcji w czasie aż do osiągnięcia jej intensywności). Z kolei prefiks $n \boldsymbol{a}$ - w nachylić się wprowadza znaczenie saturatywne, a w nakręcić się, naschylać się - znaczenie saturatywne i akumulatywne (sumowanie porcji akcji).

\section{Literatura}

Bojar B., 1979, Opis semantyczny czasowników ruchu oraz pojęć zwiąanych $z$ ruchem, Warszawa.

GrZEgorCZyKowa R., 1984, Zarys stowotwórstwa polskiego. Stowotwórstwo opisowe, Warszawa.

JanowsKa A., 1999, Funkcje przestrzenne przedrostków czasownikowych w polszczyźnie, Katowice.

LAsKowsKi R., 1999, Kategorie morfologiczne języka polskiego - charakterystyka funkcjonal$n a$, [w:] R. Grzegorczykowa, R. Laskowski, H. Wróbel (red.), Gramatyka współczesnego języka polskiego. Morfologia, t. 1, Warszawa, s. 151-224.

PRZYbYLSKa R., 2006, Schematy wyobrażeniowe a semantyka polskich prefiksów czasownikowych do-, od-, prze-, roz-, u-, Kraków.

SEBr: A. Brückner, Stownik etymologiczny języka polskiego, Kraków 1927.

STRIEKA£OWA Z., 1962, Budowa slowotwórcza czasowników ruchu we współczesnym języku polskim, „Poradnik Językowy” nr 1, s. 205-235.

15 Interesujące wnioski mogłaby przynieść analiza znaczeń omawianych w artykule przedrostków z punktu widzenia schematów wyobrażeniowych, z którymi niewątpliwie wiąże się rozpatrywana kategoria czasowników zmiany pozycji ciała (zob. Przybylska 2006). 
Śmiech W., 1986, Derywacja prefiksalna czasowników polskich, Wrocław.

USJP: S. Dubisz (red.), Uniwersalny słownik języka polskiego, Warszawa 2003 [CD-ROM]. Wiland B., 2012, Prefix Stacking, Syncretism and the Syntactic Hierarchy, [w:] M. Zikova, M. Docekal (red.), Slavic Languages in Formal Grammar, Frankfurt am Main, s. 307-324. Wróвel H., 1999, Czasownik, [w:] R. Grzegorczykowa, R. Laskowski, H. Wróbel (red.), Gramatyka współczesnego języka polskiego. Morfologia, t. 2, Warszawa, s. 536-582.

\section{Word-formational features of verbs denoting change of position with respect to the axis of the body Summary}

The paper presents word-derivational features of verbs which co-occur with sie and denote a change in the position of the body with respect to its vertical axis. The analysis shows how differences in the morphological structure of these verbs influence the manner in which the change of the position of the body proceeds. Moreover, the paper shows which elements of the meanings of verbs are carried by prefixes with which these verbs combine. The article also shows which of the morphological forms of the analysed verbs are primary, and what derivational relations hold between them and their derivatives. 